Kafkas Üniversitesi Sosyal Bilimler Enstitüsü Dergisi

Kafkas University Journal of the Institute of Social Sciences

Sonbahar Autumn 2019, Ek Sayı Additional Number 2, 407-411

\title{
ERZURUM'DAKİ 2. ALAADDİN KEYKUBAT VE ANNESİ GÜRCÜ HATUN'A AİT OLDUĞU DÜŞÜNÜLEN KÜMBET KAZISI HAKKINDA
}

\author{
Muhammet ARSLAN
}

Dr. Öğr. Üyesi, Kafkas Üniversitesi

Fen-Edebiyat Fakültesi Sanat Tarihi Bölümü

muhammetarslan25@gmail.com

Ezirmik Kümbet Kazısı Bilimsel Danıșmanı

ORCID ID: 0000-0002-5964-7007

Çalışmanın Türü: Editör'e Mektup

\section{Sayın Editör,}

Bildiğiniz üzere, Erzurum'un Pasinler ilçesine bağlı Ezirmik Köyü’nde Anadolu Selçuklu Sultanı 2. Alaaddin Keykubat ve annesi Gürcü Hatun (Tamara)'a ait olabileceğini düşünerek yapmış olduğumuz kümbet kazısı uluslararası ve ulusal basında oldukça geniş yer buldu. Bu vesileyle çalışmamızın bilim dünyasına duyurulması amacıyla mektubumu kabulünüz için teşekkürlerimi sunmak isterim.

Çağdaş kaynakların Sultan 2. Alaaddin Keykubat ve annesi Gürcü Hatun'un Erzurum'da öldüğünü/öldürüldüğünü ve buraya defnedildiklerinden bahsetmesi, köy halkının burayı "Sultan Alaaddin Türbesi" olarak adlandırması, İbrahim Hakkı Konyalı'nın yanlış yorumladığı, ancak bize yol gösterici bir kitabe okuması ve kazı öncesinde kümbet kalıntısının Selçuklu mimarisini hatırlatan bir form izlenimi vermesi gibi bilimsel nedenlerden dolayı burasının Sultan 2. Alaaddin Keykubat ve annesi Gürcü Hatun'a ait olabileceği düşünülmüştür.

\section{Şöyle ki;}

Anadolu Selçuklu tarihinin en kudretli Sultanı olarak bilinen 1. Alaaddin Keykubat, daha ölmeden oğlu 2. Gryaseddin Keyhüsrev'i Bagratlı Kraliçesi Rusudan'ın kızı Tamara ile nişanlar. 2. Keyhüsrev babası ölünce tahta geçer ve yapılan nişanı düğünle sonlandırmak için müstakbel eşi Tamara’yı Anadolu'ya getirtir ve evlenir. Ancak Sultan 2. Giyaseddin Keyhüsrev, Tamara ile evlenmeden önce iki evlilik daha yapar ve bu evliliklerden 2. İzzeddin Keykavus ile 4. Rükneddin Kılıçarslan dünyaya gelir. Sultanın üçüncü evliliği olan ve artık Anadolu'da "Gürcü Hatun" adıyla anılacak olan karısından ise 2. Alaaddin Keykubat doğar.

Sultan 2. Gıyaseddin Keyhüsrev’in Gürcü Hatun'a oldukça değer verdiği, devlet işlerini bir kenara bırakıp sürekli onunla ilgilendiği ve hatta sikkelerde ısrarla onun resmedilmesini isteyecek kadar da cüretkâr olduğu bilinmektedir. Sultan Keyhüsrev, Gürcü Hatun'a vermiş olduğu değerin bir sonucu olarak, daha ölmeden ondan doğan en küçük oğlu 2. Alaaddin Keykubat'1 veliaht ilan eder. Ancak Sultan Keyhüsrev'in ölümünden sonra devlet ileri gelenleri geleneğe uyarak en büyük abileri olan 2. İzzeddin Keykavus'u tahta çıkarırlar. Devlet ise Kösedağ bozgununu 
yaşamış ve Moğolların baskısı altına çoktan girmişti. Bu arada ortanca kardeş olan 4. Kılıçarslan abisine vekâleten Moğol Hanı'nın huzuruna çıkar ve yarlık alarak kendisini Sultan ilan eder. Babası tarafindan veliaht tayin edilen 2. Alaaddin Keykubat ise hak iddiasını devam ettiriyor olmalıdır. Dönemin önemli devlet adamlarından Celaleddin Karatay, Devlet'in bölünme tehlikesine karşın üç kardeşi aynı anda tahta çıkarır ve böylece Anadolu Selçukluları tarihinde "üç kardeş dönemi" başlar.

En büyük abi 2. İzzeddin Keykavus, Moğol Hanı'nın düzenlediği kurultaya katılmak için yola çıkar ve Sivas'a vardığında Celaleddin Karatay’ın ölüm haberini alınca Konya'ya geri dönmek zorunda kalır. Moğol Hanı'na da bir mektup göndererek durumu bildirir ve kendi yerine aynı zamanda Sultan olan kardeşi 2. Alaaddin Keykubat'1 göndereceğini belirtir. 2. Alaaddin Keykubat, Seyfeddin Torumtay, Şücâeddin Abdurrahman ve Lala Bedreddin Muslih gibi devlet adamlariyla birlikte yola koyulur ve Erzurum'a kadar gelir. Erzurum'da dinlenmeye çekilir. Bunun gecesinde kendisi için bir ziyafete katılır ve uykuya geçer. O gecenin sabahında Sultan burada ölü bulunur. Hem çağdaş hem de güncel tarihçiler bu ölümle ilgili çeşitli iddialar ortaya atarlar. Bazıları normal ölüm olarak değerlendirirken, bazıları da "Sultan’ın Moğolistan'dan yarlık alıp döneceği korkusuyla" zehirlendiğini düşünürler. Hatta bunun için de Lala Bedreddin Muslih'in görevlendirildiğini iddia ederler.

Yukarıda da görüldüğü üzere, dönemin çağdaş kaynakları Anadolu Selçuklu Sultanı 2. Alaaddin Keykubat'ın Erzurum'da öldüğü konusunda hemfikirdir. Sultan'ın Erzurum'da öldüğü/öldürüldüğü iddialarına paralel Niğgeli Kadı Ahmet'in "Gürcü Hatun öldüğünde Erzurum'a oğlunun yanına defnedildi” şeklinde daha detaylı bir bilgi vermesi ise son derece önemlidir.

Hal böyleyken; Erzurum çevresindeki Ortaçağ kümbetlerini yeniden araştırmaya başladığımızda köy halkı tarafından "Sultan Alaaddin Türbesi” olarak adlandırılan bu kümbet kalıntısına ulaşılır. Köylülerin söz konusu kümbeti bu şekilde tanımlaması basit bir olay olarak görülmemeli. Ta öteden beri, dedelerden torunlara kadar ulaşan bir tanımlama olduğu aşikârdır. Bu tanımlama bazı sorular sormamıza neden olur: buraya neden "Alaaddin Bey Türbesi", "Emir Alaaddin Türbesi” veyahut "Şeyh Alaaddin Türbesi” dememişler de "Sultan Alaaddin Türbesi”" demişler? Çünkü "Sultan" sıfatı bambaşka bir şey; iktidarı ve gücü temsil eder. Durduk yere bir yapı kalıntısını "Sultan" adıyla anmamaları gerekir, bunun altında muhakkak oldukça eski bir hatıranın kuvvetli izleri olmalıdır.

İbrahim Hakkı Konyalı'nın 1960'larda kaleme aldığı “Abideleri ve Kitabeleri İle Erzurum Tarihi" adlı kitabında bu yap1 anlatılır. Kümbet ta o dönemlerden beri kalıntı halindedir. Konyalı, o dönem yüzeyde bulduğu sandukanın üzerindeki kitabeyi de okumaya çalışır. Onun gördüğü dönemde sanduka daha sağlamdır ama yine de yazıların yer yer okunamadığından dert yanar. Şimdi ise yazılar daha kötü durumda ve maalesef bir kısmı da kırık. Konyalı, oldukça tahrip olduğundan dolayı sanduka üzerindeki kitabenin ancak bir kısmını okur, ancak farklı 
bir şekilde yorumlar. Bunun bir Bey ya da Emir'e ait olabileceğini düşünür. Hâlbuki sanduka üzerinde yazan "Galip Sultan" şeklindeki bir ifade, bunun bir Bey ya da Emir'i nitelendirmediği, doğrudan "Sultan" olan birisini nitelendirdiği gayet açıktır. Burada şunu da düşünmek gerek; Sultan olmayan birinin kitabelerde "Sultan" olarak nitelendirilmesi savaş nedeni olsa gerek! Konyalı ayrıca, "Galip Sultan" ifadesinden sonra gelen "Alaaddin"i ise maalesef isim olarak tanımlar. Halbuki "Alaaddin", isim değil sıfattır ve bunu Ortaçağ Anadolusunda kimlerin kullandığı da bilinmektedir. Konyalı, sonrasında da bu kişinin ta Yavuz Sultan Selim zamanına kadar emaret şeklinde yaşayan Saltukoğullarından bir Bey'e ait olabileceğini düşünerek konuyu kapatır.

Haliyle sanduka kitabesindeki "Galip Sultan Alaaddin" ifadesi bizim için çok önemli bir ipucu. Biz bu sandukanın Sultan'a ait olduğunu değil, Sultan'ın ailesinden veyahut dönemin Devlet adamlarından birine ait olabileceğini düşünüyoruz. $\mathrm{Bu}$ sanduka her kime ait olursa olsun, Sultan Alaaddin'i nitelendirmesi nedeniyle biz bilimsel olarak hem Sultan'1 hem de annesini burada aramak zorundayız. Bu keşif için bu ifade yeterlidir.

Yukarıda anlatılan bilimsel verilerden hareketle Anadolu Selçuklu Sultanı 2. Alaaddin Keykubat ve annesi Gürcü Hatun'a ait olduğunu düşünerek yapmış olduğumuz kazı çalışmalarında ${ }^{1}$; kazı öncesinde neredeyse tamamen toprak altında olan, gövdeye ait iç beden duvarlarının kısmi olarak görüldügü ve köylülerin anlatımı ile defineciler tarafından yaklaşık 10-15 yıl önce iş makinesiyle kaçak kazı yapılan kümbetin hem iç hem de dış etrafı açılmış, kazı sonunda kümbetin içten ve dıştan silindirik gövdeli bir planda inşâ edildiği anlaşılmıştır. Kümbet; içten içe 6.43 m., dıştan dışa $8.43 \mathrm{~m}$. boyutlarındadır. Merkezden duvara uzaklığı (yarıçapı) 3.215 m.dir. Gövdesinin en alt sırasındaki bir dizilik kesme taş örgüsü mevcuttur. Bu dizinin hemen altında moloz taş örgülü cenazelik katı başlamaktadır. Gövde alt taş dizisinden itibaren yaklaşık $0.70 \mathrm{~cm}$. derinlikte cenaze katının tabanına ulaşılmış ve burada üçü kuzeybatı köşede yan yana olmak üzere mezarlar tespit edilmiştir. Bu mezarların Horasan harçlı tuğla ile örüldüğü ve kısmi oranda yıkıldığı anlaşılmıştır. Yine cenazelik katının tabanında doğu köşede blok taşlarla örülü bir diğer mezar bulunmuştur. Güneyde ise kare şekilli tuğlalarla örülen diğer mezar daha tespit edilmiștir. Kazı sonunda mezarların üstü geotekstil keçe malzeme ile kısmi korunma altına alınmıştır.

1 Erzurum Müze Müdürlüğü Başkanlığı ve bilimsel danışmanlığımdaki kazı çalışmalarına 01.08.2019 günü başlanmış ve 09.08.2019 günü tamamlanmıştır. Kazı çalışmalarımıza Erzurum Müze Müdür Vekili Hüsnü GENÇ ile Erzurum Müze Müdürlüğü Uzman Sanat Tarihçilerinden Özlem TİMUR ve Nurgül AKBABA eşlik etmişlerdir. Ayrıca Atatürk Üniversitesi Edebiyat Fakültesi Sanat Tarihi Bölümü'nden Arş. Gör. Muhammed Burak GÖKLER ile Doktora öğrencisi Muhammed Emin DOĞAN da katkı sunmuşlardır. Hepsine fedakâr çalışmalarından dolayı teşekkür ederim. 
Kazı çalışmaları esnasında çok sayıda iskelet parçası ele geçirilmiştir. Kaçak kazılar nedeniyle hiçbir cenaze düzenli olarak ele geçirilmemiş, tüm iskeletler parçalı halde tespit edilmiş ve tamamen alınarak korunaklı bir şekilde Erzurum Müze Müdürlüğü'ne nakledilmiştir. Ayrıca yine kazı çalışmaları esnasında cenazelik katının güneyinde $1.91 \mathrm{~m}$. boyunda ve $0.38 \mathrm{~cm}$. eninde baş şahideli bir taş sanduka tespit edilerek Erzurum Müzesi bahçesine taşınmıştır. Üzerinde herhangi bir yazıt bulunmayan sandukanın baş yüzünde bir şamdan, ayak yüzünde ise profilli bir üçgen içerisine işlenmiş, üst tarafı kırık bir kandil motifi görülmektedir. Dış beden duvarlarının kuzeybatı köşesinde ise iki ayrı çocuk taş sandukası bulunmuştur. Üzerlerinde herhangi bir yazı ve süsleme bulunmamaktadır.

\section{Sonuç}

İşte bu veriler ile kazı öncesi ve sonrası elde edilen buluntular ışığında Anadolu Selçuklu Sultanı 2. Alaaddin Keykubat ve annesi Gürcü Hatun'un bu kümbete defnedildikleri kuvvetle muhtemel görülmektedir. Bu iddiaları kanıtlamak ve kesinleştirmek amacıyla, toplanan kemik ve diş örnekleri üzerinde DNA testi yapılması ve daha önce Konya'daki Sultanlar Türbesi'nden alınan DNA örnekleri ile karşılaştırılması sureti ile kümbetin kime ait olduğunun kesinleştirilmesi ve şayet Selçuklu Sultanına ait ise de zehirlendiği iddialarının araştırılmasını hedeflemekteyiz. Ayrıca İbrahim Hakkı Konyalı tarafından okunmaya çalışılan, ancak günümüzde oldukça tahrip durumda olan sanduka kitabesinin de çeşitli yöntemlerle okunması sağlanarak bilimsel bir sonuca ulaşılması hedeflenmektedir.

\section{Saygılarımla}

\section{KAYNAKLAR}

Bakır, A. (2008). Yazıcızâde Alî’nin Selçuk-nâme isimli eserinin edisyon kritiği. Yayımlanmamış Doktora Tezi. Marmara Üniversitesi, İstanbul.

Beygu, A. Ş. (1936). Erzurum tarihi, anttlarl, kitabeleri I. İstanbul: Bozkurt Basımevi.

Çevik, M. (2016). Selçuklu sultanlarının Moğol hanlarını ziyaretleri (1246-1259) ve bu ziyaretlerin Anadolu'ya etkileri. Tarih Okulu Dergisi, 9, XXVII, 43-71.

Çevik, M. (2017). Müşterek saltanatın küçük ortağı: II. Alâeddin Keykubad. Cappadocia Journal of History and Social Sciences, 9, 345-356.

Ebü'l-Ferec İbnü'l-İbrî (2011). Târîhu muhtasari'd-düvel (Türkçeye Çeviren: Şerafeddin Yaltkaya). Ankara: Türk Tarih Kurumu Yayınları.

Ertuğrul, A. (2105). Niğdeli Kadı Ahmed'in el-veledü'ş-şefîk ve'l-hâfidü'l-halikk' (Anadolu Selçuklularına dair bir kaynak) I. Ankara: Türk Tarih Kurumu Yayınları.

Hamdullâh Müstevfî-i Kazvînî (2015). Târîh-i güzîde (Zikr-i pâdişâhân-i Selçukiyân) (Editör: Erkan Göksu). İstanbul: Bilge Kültür Sanat Yayıncılık.

Hamdullâh Müstevfî-i Kazvînî (2018). Târîh-i güzîde (Çeviren: Prof. Dr. Mürsel Öztürk). Ankara: Türk Tarih Kurumu Yayınları.

İbn Bibi (El-Hüseyin B. Muhammed B. Ali El-Ca'feri Er-Rugadi) (1996). El avamirü'l-Ala'iyye fi'l umuri'l-Ala'iyye (Selçuk-name) II (Çeviren: Prof. 
Dr. Mürsel Öztürk). Ankara: T. C. Kültür Bakanlığı Yayınları

Kaymaz, N. (2014). Anadolu Selçuklu sultanlarından II. Glyâsü'd-dîn Keyhüsrev ve devri. Ankara: Türk Tarih Kurumu Yayınları.

Kerîmüddin Mahmud-i Aksarayî (2000). Müsâmeretü'l-Ahbâr (Çeviren: Prof. Dr. Mürsel Öztürk). Ankara: Türk Tarih Kurumu Yayınları.

Konyal1, İ. H. (1960). Abideleri ve kitabeleri ile Erzurum tarihi. İstanbul: Erzurum Tarihini Araştırma ve Tanıtma Derneği Yayınları.

Sümer, F. (2002). Keykubad II. TDV İslâm Ansiklopedisi, 25, 359-360.

Turan, O. (2017). Selçuklular zamanında Türkiye. İstanbul: Ötüken Neşriyat.

Yazıcızâde Alî (2014). Selçuk-nâme indeksli tıpkıbasım (Hazırlayan: Abdullah Bakır). Ankara: Türk Tarih Kurumu Yayınları.

Yinanç, M. H. (2017). İbni Bîbî Selçuknâme (Hazırlayanlar: Refet Yinanç-Ömer Özkan). İstanbul: Kitabevi Yayınları. 